\title{
United States - Preliminary Determination with Respect to Certain Softwood Lumber from Canada: What is a Subsidy?*
}

\author{
BY \\ HENRIK HORN \\ Institute for International Economic Studies, Stockholm University Centre for Economic \\ Policy Research, London \\ AND \\ PETROS C. MAVROIDIS \\ University of Neuchâtel and Columbia University Centre for Economic Policy Research, \\ London
}

\section{Introduction}

In August 2001, the United States Department of Commerce (USDOC) issued a preliminary determination that Canadian schemes for allocating standing timber to private harvesters - "stumpage" programs - provided countervailable subsidies to Canadian softwood lumber producers. It also preliminarily determined that critical circumstances existed in the US softwood lumber industry, caused by Canadian imports. Provisional measures were imposed on the basis of a preliminary subsidy rate of 19.31 percent, applicable to all producers/exporters, and applied to all entries of softwood lumber from Canada.

As an immediate response to the publication of the USDOC determination, Canada requested the establishment of a WTO panel. In its complaint, Canada argued that the USDOC Preliminary Countervailing Duty Determination (CDC), as well as the Preliminary Critical

* We are grateful to Gene Grossman, Johan Stennek and the other Reporters in the project for helpful exchanges. We have also benefited from editorial assistance by Michael Greenwald and Christina Lönnblad. 
Circumstances Determination, violated various provisions in the Subsidies and Countervailing Measures (SCM) Agreement, as well as Art. VI:3 of GATT 1994. Canada also claimed that the US countervailing duty (CVD) law regarding expedited and administrative reviews, and the application of that law to the importation of Canadian softwood lumber, violated various provisions of the SCM Agreement.

Broadly speaking, the Panel found that the USDOC did not undertake an adequate countervailing duty determination, and that the CVDs imposed on the basis of this determination thus were illegal. The Panel also found that the SCM Agreement did not allow for the retroactive application of provisional measures, but that the US CVD law concerning expedited and administrative reviews was legal under the agreement.

The purpose of this chapter is to comment on some of the issues discussed in the Panel report that are of particular interest from an economic perspective. ${ }^{1}$ The Panel in US - Softwood Lumber did not interpret its task as to make a de novo analysis of the degree of subsidization of Canadian lumber producers, but instead to determine whether the US had adequately demonstrated such subsidization. Similarly, this chapter will not seek to evaluate whether the Canadian stumpage programs actually subsidized their lumber producers, but whether the argumentation by the Panel seems to "make sense" from an economic angle, pointing to aspects of the SCM Agreement where there seems to be a conflict between the law, as interpreted by the Panel, and what makes good economic sense. ${ }^{2}$

The economics of this dispute is complicated for several reasons. A first reason is the market structure of the industry involved. Provincial governments own most, but not all, standing timber in Canada. The timber is harvested by private companies, which then sell the logs as inputs into

${ }^{1}$ WTO Panel Report United States - Preliminary Determination with Respect to Certain Softwood Lumber from Canada (WT/DS236/R, WT/DS178/AB/R, 27 September 2002); the dispute is here referred to as US - Softwood Lumber.

2 This dispute concerned a preliminary determination by the USDOC. The final determination was also challenged by Canada, and a Panel and an Appellate Body report have been issued during the writing of this report. (United States - Final Determination with Respect to Certain Softwood Lumber from Canada (WT/DS257/R, 29 August 2003), and WT/DS257/AB/R, 19 January 2004). Those determinations will be discussed in next year's reports. We merely note that the determination by the $\mathrm{AB}$ in the latter dispute is inconsistent with some of the findings of the Panel in this dispute. 
sawmills or pulp mills. Sawmills, in turn, produce softwood lumber, among other products. The lumber is partly sold outside the industry, but it may be bought by remanufacturing firms for further processing. The US countervailing duty determination concerned softwood lumber imported from Canada, whereas the measures alleged to give rise to subsidization were contracts between Canadian provincial governments and harvesters of standing timber. The nature of the vertical relationship in the industry therefore plays a central role in the dispute.

Another difficulty in this dispute is the complicated nature of the contractual terms under which standing timber is turned into logs. A party interested in harvesting timber must normally enter an agreement with a provincial government, even though (important for this dispute) there are also private suppliers of stumpage. This agreement the stumpage contract - stipulates the conditions under which the standing timber can be harvested. The agreement typically involves a number of obligations on the part of the harvester, such as requirements to build and service roads and protect against fire, as well as possible minimum or maximum cut requirements. There are also charges levied on the harvested volumes, so-called stumpage fees. These contracts differ in structure among the Canadian provinces, and each province typically employs several contractual forms that differ in a number of ways. Hence, the dispute does not concern a single easily described measure, but a large number of complex and often different types of contracts.

The structure of the chapter is the following. The next section very briefly sketches the role of CVDs in trade agreements, from the point of view of economic theory. Section 3 examines whether Canadian provincial governments can be said to provide goods. Section 4 discusses the central issue of how to define the no-subsidy benchmark against which one is to compare the actual situation. It also points to problems with the benchmarks suggested by the US, and Canada and the Panel, respectively. Section 6 reflects on the link between benefits to Canadian lumber producers and injury to US competitors. Section 7 concludes.

\section{The purpose of the CVD instrument in the SCM Agreement}

Adjudicating bodies should interpret provisions in light of their purposes and context. The SCM Agreement forms part of a larger trade agreement, and we therefore need to set the stage by first identifying the role of the 
SCM Agreement in this larger agreement, as seen from an economic perspective. $^{3}$

Following the bulk of the formal literature on trade agreements, we will view governments as interacting strategically with trading partners, and the gains from a trade agreement stem from its influence on the outcome of this interaction. ${ }^{4}$ Governments may possibly seek to maximize national social welfare, but much more plausibly they put more weight on the wellbeing of certain groups, such as import-competing industry, than on, say, consumer welfare. We therefore need to understand the role of an SCM Agreement among such governments, and how it should be interpreted for the governments to achieve their objectives as far as possible. This approach differs from a more conventional, positive economic approach, which assumes that governments seek to maximize welfare, possibly constrained by "political realities," or a conventional normative approach that evaluates outcomes with a social welfare yardstick. ${ }^{5}$

The basic rationale for trade agreements from such a perspective is that when national governments make policy decisions, they typically do not put the same weight on foreign interests as on domestic interests. As

${ }^{3}$ Fuller discussions of the rationale of CVDs and the SCM Agreement can be found in Bagwell and Staiger (2002), Grossman and Mavroidis (2003), Janow and Staiger (2003), and Sykes (2003).

4 An alternative view of trade agreements is that they affect the interaction between governments and their respective private sectors. For instance, in an industry a government might prefer a situation with a low tariff and wages low enough to maintain a high level of employment to one in which the tariff is higher. But should unemployment threaten, it may be willing to impose a higher tariff. Wage setters may in such a case see that by driving up wages, they can trigger protection, thus increasing the surplus for firms and workers in the industry to share. A restriction on the government's possibility of bailing out - perhaps implemented through a trade agreement - might then be to the benefit of the government, since it may induce wage setters to set lower wages, knowing that they will not be bailed out even if unemployment threatens. (A very similar mechanism provides a main motive for central bank independence in monetary policy.)

${ }^{5}$ Sykes (2003) thoroughly discusses the appropriate role of subsidies and CVDs in trade agreements in general, and in the WTO in particular, from the point of view of social welfare maximization. Such an approach tends to lead to more skeptical conclusions with regard to the value of CVDs in trade agreements (and export subsidies) than the approach employed here. But Sykes (2003) draws very similar conclusions concerning for instance the inadequacy of the SCM Agreement to deal with subsidies of the type alleged to exist in US - Softwood Lumber. In our view, neither approach is more correct than the other. Instead they reflect different "mandates" for the analyst, our "mandate" being narrower, accepting the outcome of the domestic political process as reflecting the country's preferences. 
a result, these policies give rise to international externalities, and these spillovers on other country governments are often negative. For instance, a tariff may benefit an importing country government by improving that country's terms of trade. But the improvement of one country's terms of trade is a worsening of someone else's, and the combined effect is often to reduce the (loosely speaking) combined welfare of the governments; the measure thus constitutes a beggar-thy-neighbor policy. The importing country government does not have an incentive to give up its protectionist policy unilaterally. But if its producers face similar treatment in their export markets, it might benefit from a reciprocal reduction in tariffs. A trade agreement codifies such a concerted move.

At stake in US - Softwood Lumber is an alleged subsidy to the production of logs that stimulate exports, and such subsidies in general have more ambiguous impact than tariffs. For the importing country, there is a presumption that a subsidy is beneficial in the aggregate by reducing the price at which a country can import. However, the consequences of the subsidy are likely to be unevenly distributed in the importing country: buyers of the imported product benefit from the discount the subsidy provides, while import-competing producers (and possibly also providers of inputs to the industry) are likely to lose. The combined effect on the importing country, as perceived by the government, depends on the magnitude of these counteracting effects, and how the government weighs them. Under certain conditions, such as when the government seeks to maximize social welfare and the industry at hand is perfectly competitive, the net effect is positive. But, depending on its preferences, the government may also see the losses to the import-competing industry as dominating the gains to consumers.

For the exporting country, a subsidy is costly since it provides a discount on the price at which the trading partner purchases its imports. But certain groups in the exporting country are likely to gain, and the exporting country government may find that these gains dominate the cost to other groups, such as, for instance, taxpayers. It is therefore possible that the subsidy may simultaneously benefit the exporting country government, and harm the importing country government.

Production subsidies are generally legal under the SCM Agreement, but can under certain conditions be countervailed by importing countries. There is a strong presumption that subsidization benefits the importing 
country government when it has access to CVDs. ${ }^{6}$ The importing country government can set CVDs so as to restore the price prevailing absent the subsidy, thereby leaving domestic consumers and producers unaffected by the subsidy. But in the process, it collects tariff revenue, and is therefore better off than without the subsidy. In other words, the CVD instrument ensures that importing countries can neutralize negative externalities from the subsidy. Importing countries may also prefer to offset just part of the subsidization, letting the rest pass through to domestic buyers. If the exporter continues to subsidize in such a situation, such a subsidy will presumably be beneficial to both the importing and the exporting country government. ${ }^{7}$

As can be seen, the CVD instrument has certain virtues. However, there are reasons to suspect that due to the way it is implemented through the SCM Agreement, the level of CVDs will not be optimal from the point of view of the Membership as a whole. The decision to implement the CVD rests with the importing country only. When this country decides whether to countervail, it will probably not take into consideration the positive effects of the subsidy for the exporting country government. If so, the importing country may expose the exporting country to a negative externality in its choice of CVD. This suggests a reason why the SCM Agreement allows for too large CVDs. ${ }^{8}$

${ }^{6}$ Recall that we disregard domestic strategic interaction of the type mentioned above. In its presence, the CVD instrument may weaken an importing country government, since it presents a new tool for protectionism that the government has difficulty withstanding.

7 When there are several exporting countries, they may end up in a Prisoners' Dilemmatype situation where they all subsidize too much, and thus would prefer an agreement that prevents subsidization.

${ }^{8}$ Consider the following simplistic illustration of the inefficiency that might arise. Country A produces a certain gadget in a remote region. The government (and people in general) in A puts great value on maintaining the traditional way of life in this region, which is based on the production of this gadget. The whole produce of gadgets is exported to country B, which also maintains a small local production thereof. This small industry also suffers economic problems. However, there is no special value attached to gadget production in $\mathrm{B}$, and it would be easy for gadget producers and employees to find alternative sources of income. If country A were now to subsidize its production to help maintain this traditional lifestyle (subsidizing incomes would for some reason not be as effective), country B could offset this subsidy to the full extent of the benefit it yields to country A producers. This would clearly not be an efficient outcome for the two countries combined. For instance, it might well be the case that country A would be willing to fully compensate B for the minor harm it suffers from the subsidy, if it could be maintained. Again, we should recall the assumed absence of domestic strategic interaction. With such interaction the exporting country government may be better off, being better able to withstand domestic pressure for subsidies the government would prefer not to implement. 
A second reason why the CVDs permitted by the SCM Agreement may be of inappropriate magnitude is the fact that they are to be calculated on the basis of the benefit to the exporter. As argued, the purpose of the WTO Agreement in general, and also the SCM Agreement, should reasonably be seen as to prevent harm to trading partner interests from nationally pursued policies. It seems highly unlikely that this will be achieved when the magnitude of the CVD is calculated solely on the basis of the benefit to the exporters. ${ }^{9}$

We now turn to the Panel's findings with regard to the claims by Canada concerning the USDOC's Preliminary CVD Determination. The first is the question of whether Canadian provincial governments can be said to be providing goods. If not, they could not from an economic point of view (nor legally) be subsidizing lumber production.

\section{Do Canadian provincial governments "provide goods"?}

According to Art. 1.1 SCM Agreement a subsidy to a good is deemed to exist if

there is a financial contribution by a government or any public body ... i.e., where:

(i) a government practice involves a direct transfer of funds...

(ii) government revenue that is otherwise due is foregone or not collected...

(iii) a government provides goods or services other than general infrastructure...

(iv) a government makes payments to a funding mechanism ...

...

and $\ldots$ a benefit is thereby conferred.

In its determination, the USDOC claimed that Canadian provincial governments had provided financial contributions in the sense of point (iii), that is, by providing goods rather than by making financial payments, which would occur in the situations exemplified in points (i), (ii) and (iv). A central issue therefore is whether the challenged measure involves provision of goods.

9 The fact that Art. 19 SCM Agreement states that it is "desirable" that CVDs be not larger than what is adequate to remove the injury does not seem importantly to affect this conclusion. 
Canada claimed that stumpage programs do not "provide goods" in the sense of the SCM Agreement, for several reasons. For instance, according to Canada, stumpage is not a "good" but a property right. And even if stumpage contracts are taken to provide standing timber, such timber is not a "good" since it cannot be traded (and thus lacks customs classification). It is not "provided" by the governments, since there is no positive action on the part of provincial governments, which only allows the harvesters to cut the timber.

The Panel refuted Canada's arguments, determining that stumpage programs provide standing timber, and that standing timber is indeed a "good," as argued by the US (7.16-7.18).

In our view, the Panel's determination makes good economic sense. The provincial governments initially own the standing timber. But by entering into a contract with such a government and fulfilling the associated obligations, a private party obtains the right to enter the land, cut trees, and remove the logs from the land, and it also obtains ownership over the logs. The contract specifies the volume that can (and sometimes must) be cut. There are financial payments related to the volume taken out. The harvester is also required to undertake various costly measures, such as silviculture, building and maintenance of roads, etc, which presumably benefit the government. It is hard not to see these costs as a partial payment by the harvester for the timber it is taking out; if the harvester did not have the right to harvest, the firms would not have any reason to enter into these contracts. The total "price" paid for the timber is, of course, not only the volume-dependent fee, but also includes the various forestry management measures stipulated in the contract. In economic jargon, the price is thus highly "non-linear," since the total payment is not proportional to the purchased volume.

Several comments are in order:

First, the conclusion that the costs borne by the harvester are to be seen as the price paid in order to transfer the ownership of the timber to the harvester, is unaffected by the fact that provincial governments may at least partly have other interests than raising revenue when designing these contracts, such as environmental concerns. Normally, the motives why a private entrepreneur provides a product do not have to be taken into account; whether it is to make a financial profit, to become famous, for enjoyment, or whatever, the entrepreneur is nevertheless providing the product. Similarly, governments' objectives are immaterial to the question of whether they are supplying standing timber, at least from an economic point of view. 
Second, and contrary to what was argued by Canada, it is also immaterial whether the timber is "delivered" standing; a physical item is nevertheless transferred from one owner to another. ${ }^{10}$ The government could cut the timber and just leave it where it falls. The timber would then be physically mobile, like any other product. Naturally, this would not be of importance for the economic question of whether the product is supplied or not. More generally, the fact that the purchaser must undertake certain actions before the product can be used lacks significance from this point of view. Most goods have to be picked up at a different location than where they will be consumed, and actions such as unwrapping are necessary before they can be used. Nevertheless, the products are supplied to the buyers.

Third, Nordhaus (2001) argues that timber-harvesting rights are essentially options and that stumpage charges are payments for exercising these options, and thus cannot be seen as "prices." It might indeed be useful to view these arrangements as options. This suggests that the whole agreement, and not just the variable charges, must be considered, and also that the extent to which the harvesters will use the option may be uncertain at the contracting date. But the fact that the contract allows the harvester to decide unilaterally at a later date whether to cut a specified amount of timber and then pay a certain fee per unit does not change the basic fact that this "option contract" specifies the terms under which timber that initially belongs to the government is cut and removed by the harvesters. Clearly, an option contract can have more or less favorable terms for the buyer, and can implicitly subsidize the buyer or someone else downstream if the buyer is an intermediary, relative to some benchmark. ${ }^{11}$

Fourth, Nordhaus (2001) suggests yet another reason why the terms of stumpage should not be seen as the price paid for the supply of timber: these contracts give governments the right to unilaterally decide on the volume-dependent charges. Therefore, they are more accurately seen as taxes on the rents accruing to the harvesters from the

10 The claim that standing trees are immobile (or non-tradable) can also be challenged on factual grounds, considering the fact that there are forestry machines that effectively "pick" trees, including the roots.

11 To illustrate, a railway or bus company might offer its customers a contract whereby it pays a fixed fee in order to travel at a reduced rate during a month or a year. This can be seen as an option contract, since at the time when it pays the fixed charge, the travelers do not know how much they will travel. But the company must still be said to be providing a product (a travel service) whenever the traveler uses the bus or train. 
standing timber. However, these rents would not accrue to the harvester unless the ownership of the timber was transferred to the harvester, and stumpage fees are part of the terms of these transfers. They are therefore effectively part of the price the harvester pays for the timber. It might be argued that harvesters are uncertain about the level of these charges. This uncertainty may (depending on the way it affects the stumpage fees) weaken the impact of the stumpage fees on the incentives of tenure holders to log. But even if the total logged volume were perceived to have no impact on the total payment of stumpage fees, these fees would still be considered as part of the total cost of harvesting, even if uncertain at the contracting date.

Fifth, another special aspect of stumpage contracts is that they are often very long term. But, again, this does not fundamentally change the fact that these are the conditions under which the ownership of standing timber changes hands, and that the terms of these contracts may affect the incentives for logging. Also, and related to the previous observation, the long-term nature of these contracts should limit any uncertainty about the stumpage fees.

To conclude, the Panel's determination as well as its reasoning seem sensible from an economic point of view. From such a perspective, Canadian provincial governments must be said to supply timber, and stumpage contracts (including stumpage fees and other contractual obligations) specify the terms for the transfer of ownership of this timber. Consequently, the question of whether the terms of stumpage are such as to subsidize lumber production becomes meaningful.

\section{Is "a benefit thereby conferred"?}

For there to be a subsidy, Art. 1 SCM Agreement not only requires that there be a "financial contribution by a government" (which arises when a government provides a good), but also that "a benefit is thereby conferred." The USDOC claimed to have established that this was the case. But Canada argued that the USDOC employed an illegal, and economically inappropriate, no-subsidy benchmark when finding and measuring such a benefit.

In order to examine these issues, and the Panel's reaction to them, it is necessary to first determine how stumpage programs might benefit lumber producers and, in particular, stimulate an increased production of lumber. 


\subsection{How could stumpage programs benefit lumber producers?}

Basic economic theory suggests that for stumpage programs to benefit lumber production (relative to some benchmark), they must reduce the marginal costs of production for lumber producers. This, in turn, requires that stumpage programs reduce the price of logs. ${ }^{12}$ The most likely way for this to come about would be for stumpage programs to stimulate larger volumes of logging. Differently put, for there to be subsidization of lumber production, it must be the case that absent the alleged subsidization, there would be less logging.

There are two basic mechanisms through which governments may increase logging through the design of stumpage programs. The first is to encourage more intensive logging per acre under a stumpage contract. For stumpage programs to have this effect, they must reduce the marginal harvesting costs - among them the stumpage fees - relative to the benchmark situation. A subsidy reducing these costs would induce harvesters to cut trees that would otherwise be unprofitable to harvest. It should be noted that this consequence of a lower marginal cost is likely to show up for market structures among harvesting firms ranging from a monopoly to perfect competition.

The second mechanism through which stumpage contracts may tend to induce more production of logs is by increasing the total acreage used for stumpage. It is clear that the demand for stumpage contracts will be higher, the lower the variable costs in the contract. The demand will also be higher, the lower the fixed costs the contracts impose on harvesters in the form of obligations to construct and maintain roads, silviculture, etc. For this increased demand to result in increased logging, however, governments must be willing to respond by using more of their land for stumpage. If the governments supply a constant amount of land for harvesting, regardless of the terms of the stumpage, there will be no impact on the amount of logging working through the entry and exit of harvesters, and consequently there will be no benefit conferred to lumber producers from the subsidy to harvesters through this mechanism (any effects working through changes in the intensity of logging may still be at work, however). ${ }^{13}$

12 The argument here does not critically hinge on whether harvesters are vertically integrated with lumber producers.

13 A conventional demand and supply representation is only used for the sake of expositional simplicity, since provincial governments have significant market power, and 
It can thus be concluded that the validity of the US claim concerning subsidization, when considered from an economic angle, critically hinges on the claim that the design and supply of stumpage contracts are such as to increase logging and thereby subsidize lumber production, relative to an appropriate benchmark. A critical issue is therefore the definition of this no-subsidy benchmark.

It can also be seen that when comparing two different contract types, it is not a trivial matter to determine whether one induces more production than the other. For instance, a contract with a lower variable fee, which through this mechanism would tend to induce more output per contract, may also be associated with higher fixed costs. The latter would reduce the general profitability of logging, and thus tend to reduce output. The combined consequence of these effects may result in less logging, despite the lower stumpage fee. On the other hand, it is possible that a contract that essentially transforms marginal costs to fixed costs will induce more production, even if the total cost per stumpage contract increases. It should be emphasized that these issues cannot simply be disregarded as details, but are central to the issue at stake in this dispute.

\subsection{What should be the no-subsidy benchmark?}

The concept of a "subsidy" implicitly or explicitly relies on a comparison between two situations, one in which the subsidy exists (which is normally the actual situation) and one in which it does not. The answer to the question of what should be the no-subsidy benchmark may seem obvious: use a situation in which the contested measure is revoked. However, this is not a well-defined benchmark, since there are innumerable situations without the subsidy with which to make the comparison. But why then not choose the situation without the subsidy, ceteris paribus? There are at least two reasons why this definition of the no-subsidy benchmark is also problematic.

The first, and normally less significant, problem is that all else cannot be constant even if the importing government wanted to keep it so. ${ }^{14}$ The second reason why the ceteris paribus assumption is problematic is the fact

their behavior is therefore not readily illustrated with supply schedules (which assume price-taking behavior).

14 To see why, consider the simplest possible case in which a government provides a monetary transfer per unit of output produced. Suppose the no-subsidy benchmark is taken to be a situation where there is no subsidy transfer scheme, all else being constant. However, it is normally not possible to change only the subsidy scheme and leave 
that the government may not want to keep all else constant as the subsidy is removed, but may resort to other measures with a similar effect. Consider the following highly stylized illustration. A government has two instruments, an actionable specific subsidy of $s$ and a non-actionable lawful instrument with effects equivalent to a smaller specific subsidy $r$. The government's preferred rate of subsidization is equal to $s$. Its first choice would therefore be to use the actionable subsidy, but when unable to do so, it uses the other instrument, and provides a subsidy equal to $r$. Now let the CVD equal the difference in price with and without the subsidy. How large will it be? If the no-subsidy benchmark were taken to be the situation where neither of the instruments is used, then the CVD would equal $s$, this being the difference in price between the two situations. But if instead the no-subsidy benchmark is meant to capture the situation as it would be absent the actionable subsidy, the difference in price would be $s-r$, which is potentially a much smaller number than $s$. Differently put, the effect of the actionable subsidy is not to change the subsidy with the amount $s$ but with $s-r$.

The suggested benchmark "revoke measure, ceteris paribus" is hence associated with conceptual problems due to the ceteris paribus part. These problems may or may not be quantitatively important depending on the exact circumstances. But what appears to make this benchmark unsuitable in the case of US - Softwood Lumber is the fact that it would not be very interesting to employ a situation where the stumpage programs are simply abandoned as a benchmark. The governments own the standing timber, and in any relevant benchmark, there must be a supply of government timber to private harvesters, and this must be regulated through some form of contract that allows for the pursuit of legitimate forestry management policies. A fundamental difficulty in a case like US - Softwood Lumber is thus to identify the alternative no-subsidy type of contract.

everything else the same. For instance, without the subsidization and with all other measures unchanged, the government's accounts would not add up, since there would now be a surplus due to the unspent revenue. Consequently, some form of adjustment must take place. For instance, less revenue may be collected, the government may borrow less, or, if there is a government budget surplus, it might lend more or spend more on other goods, etc. The point is not to argue that these induced changes are likely to be quantitatively important in practice, but to illustrate the fact that the definition of the no-subsidy benchmark is conceptually unclear even in the simplest of settings. 


\subsubsection{A conceptually desirable, but impracticable, no-subsidy benchmark}

At a general level, the conceptual problems with the suggested "revoke, ceteris paribus" definition of the no-subsidy benchmark stem from the fact that it is not derived from the purpose of the SCM Agreement, or the WTO Agreement more generally. As discussed above, economic theory suggests that a main purpose is to prevent Members from pursuing policies with negative externalities on trading partners, to the extent that these negative effects are larger in magnitude than the positive effects on the countries pursuing these policies. Following the approach of Bagwell and Staiger (2002), one could naturally define the no-subsidy benchmark as a situation in which Canadian provincial governments when deciding the stumpage terms do not take into consideration the consequences for the terms of trade vis-à-vis the US, or for the market access of Canadian lumber exporters. The question would thus be whether the provincial governments would induce a smaller supply of logs if terms-of-trade and/or market access considerations were not taken into account? If so, there would be an actionable subsidy, since they would then be exposing US producers to negative externalities for beggar-thy-neighbor purposes.

A main virtue of this definition is hence that it is intimately related to the assumed purpose of the agreement, in that it neither directs Members to choose particular policies, nor to maximize some notion of global welfare, but to refrain from behaving in a beggar-thy-neighbor fashion. Another advantage is that it does not focus on just one component of a complex contract - the stumpage fees - but takes into account the combined effect of the whole contract, and it would also include the induced changes in the supply of stumpage contracts. ${ }^{15}$

${ }^{15}$ It can be noted that this notion of a subsidy does not require a positive financial payment by the government to harvesters, since a regime with positive stumpage fees may also involve subsidization. In contrast, Nordhaus (2001, p. 44) argues that under "market principles," the stumpage fee would be zero, and that a zero stumpage fee is also a feature of an efficient regulation of the industry. The virtue of a zero fee is that it does not distort the amount of logging. A positive stumpage fee would thus provide a disincentive for logging relative to the "market principles" solution, or the efficient solution, and can therefore not be part of a subsidization of lumber production. This is thus a statement concerning the properties of the benchmark situation. However, for this discussion Nordhaus (2001) "... ignore[s] market failures, public goods, and the interaction of timber management with the other forest-use objectives," aspects that elsewhere in the Nordhaus (2001) report are seen as essential characteristics of the forest industry, and which presumably would make non-zero stumpage fees socially optimal. 
Unfortunately, there are also certain drawbacks to this subsidy definition. First, it may include measures one would not want to denote as subsidies, even though they might have basically identical effects. For instance, a tax on other uses of logs than for lumber production has basically the same impact as a subsidy to lumber production, since it would reduce the price of logs for lumber producers. If this tax is set higher than it would be if the government disregarded the impact on lumber exports, then one would, according to the definition above, conclude that there is a subsidy. This subsidy would still be administered by the government, but it would come directly from the other users of logs, rather than from the subjects on which the tax would be normally levied. One may therefore want to further restrict the definition of a subsidy. ${ }^{16}$

The major drawback of this definition is, however, that it is likely to be very hard to employ in practice. For instance, it probably requires knowledge of the government's objective functions. The informational problem is exacerbated in US - Softwood Lumber by the fact that the contracts under consideration do not simply specify a single price, but establish a range of undertakings for the harvester. The no-subsidy benchmark situation is thus much harder to identify in the present case. We are thus led to conclude that a conceptually satisfactory subsidy definition is likely to be very difficult to implement in practice.

\subsection{The solution in the SCM Agreement: a private sector benchmark}

The SCM Agreement points to a very different no-subsidy benchmark; Art. 14 (d) SCM Agreement requires a benefit calculation to be made.

... in relation to prevailing market conditions for the good or service in question in the country of provision...

(emphasis added)

The idea behind this "private investor test" is hence that since the terms of the benchmark contract are strictly commercial, they will not be influenced by any incentive to subsidize.

A main issue in US - Softwood Lumber was the interpretation of this phrase. The US argued that while private sector contracts in the allegedly subsidizing country should ideally be used, this was not possible in the

16 This is done in Art. 1.1 SCM Agreement through the requirement that there should not only be a benefit but also a financial contribution. 
present case, since the Canadian private sector stumpage market was too distorted by the government subsidies to serve as a reasonable nonsubsidy benchmark. Therefore, the USDOC compared stumpage fees, adjusted for various differences in costs, with private market prices in mainly neighboring US states.

Canada, for its part, maintained that there was no legal basis for the argument that distortions of the domestic private sector prices invalidated their use as a benchmark. Canada also claimed that there is no support in the SCM Agreement for the US method of cross-border comparisons. In addition, Canada argued that there were private sector stumpage contracts that the USDOC could have used for its comparison.

The US countered that its methodology was nevertheless consistent with the object and purpose of Art. 14 SCM Agreement. The US also pointed to the fact that the provision states "... in relation to prevailing market conditions in the country under investigation...," and does not merely refer to the market conditions in this country.

The Panel basically agreed with Canada, emphasizing that the term "prevailing market conditions" in Art. 14(d) SCM Agreement strongly suggests that the benchmark should be the existing private market. In particular, the relevant benchmark should not be a hypothetical undistorted market identified through a "but for" test. Instead, the Panel held that

... the text of Article 14 SCM Agreement leaves no choice to the investigating authority but to use as a benchmark the market... as it exists in the country of provision...

(7.44, emphasis in original)

The Panel acknowledged that US prices could still be used if they could be said to be part of the prevailing market conditions in Canada. The Panel refuted this interpretation, however, stating that the US argument would imply that world market prices are part of the market conditions in the exporting country, an interpretation for which it found no support in the SCM Agreement. Such an interpretation would also effectively read out of the text the explicit reference to "the country of provision." The Panel also stated that

... [w] e note that the prices of imported goods in the market of provision can indeed form part of the prevailing market conditions ... But this is not the same as the price for those goods prevailing in the country of export....

(7.48, emphasis in original) 
Two alternative private sector benchmarks are thus suggested in this dispute. They are both beset with serious conceptual problems, however.

A first potential problem, common to both suggested benchmarks, is that private parties selling standing timber not only lack the incentive to subsidize that governments may have, but they are also likely not to share the other objectives of governments. For instance, in the case of US Softwood Lumber, provincial governments may legitimately care more about other uses of the forests than would private owners. Indeed, this might at least partly explain why the forests are publicly owned. When comparing with private sector stumpage, it is therefore important to take into consideration the extent to which differences in contract terms reflect the generally different roles of governments and private parties, rather than differences in the desire to subsidize lumber production.

But there are also other problems with the suggested benchmarks, as seen from an economic perspective.

\subsubsection{Problems with a domestic private sector benchmark}

Insisting that the benchmark is the private market "as it exists," the Panel rejected the use of a "but for" test:

...We are thus of the view that Article 14 (d) SCM Agreement does not require that the authority constructs a market price that could have existed but for the government's involvement, nor does it allow the authority to decline to use in-country prices because they may be affected by the government's financial contribution.

As discussed above, it is hard to see how the calculation of the benchmark can be made in a conceptually adequate fashion in any other way. The fact that such a test is likely to be very difficult to perform in practice is not a reason completely to reject its use, but rather to be cautious about the quality of any such test. Indeed, when claiming that the US had not demonstrated that prices of private stumpage contracts were distorted but only assumed this to be the case, Canada actually seemed to be arguing in favor of such a test: Canada was essentially requesting the US to calculate what Canadian private sector prices would be "but for" the intention to subsidize Canadian lumber producers.

The US argument against using existing Canadian stumpage contracts as a benchmark is correct from an economist's viewpoint, in that, if there is a subsidy, it might seriously distort the private sector benchmark. Whenever government stumpage contracts are designed so as to increase 
the supply of logs, the value of private stumpage is likely to be affected. In particular, the more government stumpage schemes increase harvesting, the lower will be the price of logs. The relationship between the price of logs and the price of private stumpage is not entirely clear, since this partly depends on how government stumpage contracts are allocated. But there is a presumption that the stronger the price-depressing effect of the subsidy for logs, the lower should be the willingness to pay for private stumpage, and the less informative should be private sector prices. Hence, the more pronounced the subsidization, the less useful are private sector contracts in demonstrating subsidization that harms US lumber producers. $^{17}$

It should be stressed, however, that while the US argument is correct as a matter of principle, in the sense that private sector contracts may be affected by the terms of government stumpage programs, the USDOC did not show that Canadian prices actually were distorted. It is not clear however, how such a demonstration could be made.

To summarize, there are at least two serious problems with the domestic private sector benchmark. First, WTO Members have not promised each other to let their policies mimic private sector outcomes, but not to behave in a protectionist fashion. It is not self-evident that a private market would yield the same outcome as a government pursuing forestry policy in a non-protectionist manner. Hence, the benchmark against which to compare actual behavior should not be taken from the private sector, but should be what a government without protectionist motives would do. Second, the private sector benchmark would also be likely to be inadequate to measure subsidization for the reason advanced by the US.

Finally, although this may be a misunderstanding on our part, it seems as if the Panel had some sympathy for the US argument, but felt constrained by the SCM Agreement to reject it:

[w] e wish to note that even if in certain exceptional circumstances it may prove difficult in practice to apply Article 14 (d) SCM Agreement, that would not justify reading words into the text of the Agreement that are not there or ignoring the plain meaning of the text. In our view, the text of

${ }^{17}$ It can also be noted that the outcome of a comparison with private sector contracts depends on the market structure in this industry. This implies that the outcome of the calculation of the subsidy that is to be countervailed will depend on the market structure of the Canadian private market for stumpage. This might not be a significant problem in the present case, but it does point to an additional conceptual problem with the private domestic (or foreign) market benchmark. 
Article 14 SCM Agreement leaves no choice to the investigating authority but to use as a benchmark the market...as it exists in the country of provision.

(7.53, emphasis in original)

\subsubsection{Problems with a foreign private sector benchmark}

The US argument in favor of using US prices (which are said to equal world prices) seems based on the notion that differences in the price of stumpage across countries reflect differences in the degree of illegal subsidization, and that, in a world "undistorted" by government actions, the price of stumpage should generally be the same in Canada and the US. The strongest economic basis for this notion is probably the well-known "Factor Price Equalization Theorem." Very loosely, the Theorem establishes conditions under which goods trade alone suffices to equalize factor prices across countries, despite differences in countries' endowments of such factors. If in such a world factor prices nevertheless differ, for instance, standing timber being cheaper in one country than in another, a possible explanation might be a government subsidy.

This Theorem does not provide a strong foundation to build a case in favor of using foreign private sector prices, however, since it rests on far too restrictive assumptions. Indeed, in empirical tests, it normally does not perform well. For instance, it assumes perfect competition, constant returns to scale, and identical production technologies across countries. It would be violated if, in comparison to the US, Canada were sufficiently better endowed with standing timber relative to other factors. But since it is not clear what "sufficiently better" quantitatively means, it would be very hard to determine whether differences in stumpage prices between the US and Canada are due to differences in the relative endowments of factors of production, or to government policy.

The predictions of the Factor Price Equalization Theorem may be further obscured if governments in Canada and the US pursue different policies, since this will, of course, have implications for prices in the two countries, even if all these measures are "non-protectionist." In particular, if Canadian stumpage fees are lower than those in the US, this may reflect the fact that the fixed cost obligations in stumpage contracts are more onerous in Canada than in the US, due to different policy preferences. But differences in government policies in other areas and other industries are also likely to affect prices. For instance, if capital costs are higher in 
Canada due to differences in macroeconomic policies, this will naturally affect other prices in the economy.

Yet another reason why one should not expect input prices to be equal among trading partners is the existence of trade costs, widely interpreted. There are obviously costs associated with physical transportation. However, recent empirical literature has highlighted the fact that physical distance (which should be a good proxy for physical transportation costs) is not the only barrier to international trade. National borders seem to have an important impact beyond what can be explained by distance. That is, comparing trade between two locations, A and B, in the US with trade between $A$ and a location $C$ in Canada, where the distance between $\mathrm{A}$ and $\mathrm{B}$ is the same as between $\mathrm{A}$ and $\mathrm{C}$, one will typically find substantially less trade between $\mathrm{A}$ and $\mathrm{C}$. The interpretation is that national borders are associated with trading costs beyond physical transportation, resulting, for instance, from differences in legal systems, cultural differences, the red tape involved in international trade, etc. ${ }^{18}$ These findings suggest that when Canadian lumber producers export to the US market, they are likely to receive lower producer prices, not only because of the often (but not always) higher costs of physical transportation, but also because of these border effects. These effects will thus contribute, perhaps importantly, to a lower reward in the exporting country for the factors going into lumber production, such as logs and thereby stumpage. This is yet another reason why international price comparisons are fraught with practical problems.

It follows from the above that in case the standing timber in Canada is sold through stumpage at lower prices than in the US, this need not signal any form of subsidization, but could simply reflect various underlying differences in the economic structure of these countries. ${ }^{19}$ Naturally, this argument is weaker, the more similar the two countries are in terms of economic structure. But as long as there are differences, there is no

18 See Leamer (2001) for a discussion of implications of this literature for the question of whether Canadian export restrictions on logs subsidize lumber production.

19 Another way of looking at this issue is to observe that with private ownership of forests, the remuneration received by forest owners is essentially a rent - an income bestowed on them through their ownership of a fixed amount of timber, rather than in return for some productive activity. The magnitude of this rent will depend on the profit opportunities of firms in possession of standing timber. The higher the costs for cutting the timber, for transporting it to lumber producers, for producing lumber and for transporting the resulting lumber to the US market, etc, the lower the value of the forest. Only under very special circumstances would the rents be the same in the two countries. 
presumption from an economic point of view that the lower price of government stumpage in Canada necessarily indicates the existence of subsidization. It must therefore be demonstrated that even when accounting for all the underlying differences between countries, there remain differences in price that can only be due to subsidization. Such a demonstration seems almost impossible to perform in practice.

It can be noted that the problems with international price comparisons pointed out here already arise with vertically integrated firms. When harvesters and lumber producers are at arm's length, there are additional problems involved in international price comparisons. For instance, the linkage between the market for stumpage and the lumber market will now depend on the market structure for logs; we will return to this issue in the next section.

Finally, an argument advanced by the US in favor of the practice of using US prices as benchmarks was that many Canadian companies import US logs despite the stumpage program. According to the US, this shows that the US market is part of the market available in Canada. However, it rather seems to suggest that Canadian stumpage prices are not very attractive from the point of view of Canadian buyers of logs or, alternatively, that the supply of logs is insufficient to meet demand, given the terms of stumpage. If anything, this observation seem to suggest the absence of a subsidy.

To conclude, the conceptually desirable benchmark identified above is hard to implement in practice. The domestic private sector benchmark is associated with serious conceptual problems from an economic point of view, suggesting a weakness in either the text of the SCM Agreement or possibly the Panel's interpretation thereof. And foreign sector benchmarks are virtually non-informative. Only under highly special circumstances would one expect input prices to be the same among trading partners, even absent "protectionist" policies. The Panel was thus right not to accept the US methodology in this respect.

\subsubsection{Does the degree of vertical integration matter for the benefit conferred on Canadian lumber producers?}

The Panel report discussed the pass-through from harvesters to Canadian lumber producers, in particular the importance of the degree of vertical integration for such pass-through. The US had argued that no passthrough analysis was necessary, partly because Canadian harvesters and lumber producers were not at arm's length, since most lumber producers also harvest timber. Indeed, according to the US, 
...the laws and regulations of each Canadian province (with the partial exception of Ontario) generally require that tenure holders be sawmills.

(p. A-13, para. 1)

Canada, on the other hand, maintained that a significant proportion of harvesting is done by firms at arm's-length relationships to lumber producers. For instance, more than 30 percent of the timber harvested on Crown land in British Columbia is said to be harvested by entities not owning sawmills. The essence of the arguments thus seemed to be that while the US claimed that the vast majority of Canadian lumber producers are vertically integrated with harvesters, Canada argued that a significant proportion of logging is still done by independent harvesters. The general impression we derive from this exchange is that while some stumpage contracts are open to larger foreign firms, a variety of provisions hinder this in other contracts. But determining the prevalence of such hindrances is hard, since here "the devil is in the details" to a very high degree.

The Panel viewed the main issue before it to be whether the USDOC conducted a pass-through analysis in those cases where this was legally required. In the opinion of the Panel (and also the parties), the extent of analysis required depended on the vertical relationships in the industry. In cases of vertically integrated operations, such an analysis was not necessary, according to the Panel:

... It is clear that in such circumstances of complete identity between the tenure holder/logger and the lumber producer, no pass-through analysis is required....

On the other hand,

... in such cases, where a downstream producer of subject merchandise is unrelated to the alleged subsidized upstream producer of the input, an authority is not allowed to simply assume that a benefit has passed through....

Hence, in cases of arm's-length vertical relationships,

... the investigating authority should examine whether and to what extent the subsidies bestowed on the upstream producers benefited the downstream producers.... 
The Panel pointed to the fact that the records before the USDOC at the time of its determination showed that some Canadian lumber producers had an arm's-length relationship with harvesters, and that the USDOC did not investigate whether these lumber producers benefited from the stumpage programs in these cases. The Panel thus concluded that the US acted inconsistently with the SCM Agreement in these cases. The Panel also found that the US should have performed pass-through analysis in cases where sawmills bought logs from unrelated sawmills, and where remanufacturers purchased lumber from unrelated sawmills.

As can be seen, the Panel drew a sharp distinction between cases of arm's-length relationships and vertical integration. The importance of this distinction is not obvious, however. As argued by the Panel, in the case of vertical integration it is indeed likely that a subsidy inducing more harvesting of logs also increases Canadian lumber production. But the presumption that similar effects would arise also with arm's-length relationships is almost as strong: the increase in the supply of logs is highly likely to depress the price of logs, which will stimulate lumber production. If a pass-though analysis is deemed unnecessary in the case of vertically integrated firms, it should not be necessary with arm's-length relationships either. Hence, whether the industry is vertically integrated or at arm's length seems largely immaterial to the question of whether Canadian lumber production benefits from the measure.

\section{Do benefits to Canadian lumber producers cause injury to US competitors?}

The discussion in this dispute concerning pass-through largely focused on the issue dealt with above - whether or not the Canadian lumber industry benefited from the subsidy. However, to the extent that the purpose of the WTO Agreement is to help countries get out of a Prisoners' Dilemma-like situation, the US should not be allowed to countervail unless there is injury to the US lumber industry. ${ }^{20}$ The Panel did not have to address the issue of injury, finding that the USDOC had not shown the existence of a subsidy.

To see why the existence of injury is not a foregone conclusion, consider the impact on US lumber producers of increased Canadian log

20 The method advocated by the Panel, whereby the subsidy is calculated as the ratio between the total subsidy payments and total sales, is conceptually flawed from this point of view, since it does not measure the harm to US producers. 
harvesting. Assume first that Canadian logs are not internationally tradable to any significant degree. ${ }^{21}$ Lumber producers located in Canada must then absorb the increased supply of logs, and these should mainly be Canadian firms. Hence, this would be a case in which a Canadian upstream subsidy would benefit Canadian lumber producers at the expense of their US competitors, which is the situation the US has claimed is the situation in this dispute. Note, however, that the negative effect on US producers of the subsidy is likely to arise regardless of whether harvesters and lumber producers are vertically integrated. ${ }^{22}$

Now turn to the case in which logs are fully tradable internationally. If the harvesters are at arm's length from lumber producers, any pricedepressing effect of Canadian logs will spill over and depress the prices of US logs as well. Therefore, to the extent that there is a pass-through of a subsidy to Canadian lumber producers, it benefits US producers to the same extent. Hence, in the case of arm's length relationships, the extent to which logs are tradable is of crucial importance for the impact of an increased supply of logs. This confirms the Panel's view that a passthrough analysis is necessary in this case.

The impact of the increased supply of logs is less clear in the case where Canadian logs are not tradable internationally, but where the Canadian industry is vertically integrated. Suppose for simplicity that all Canadian harvesters are integrated with Canadian lumber producers. These firms can by assumption either use the logs for their own lumber production or sell logs to US firms. What will they prefer to do? This question of whether foreclosure is feasible and profitable for Canadian harvesters-cum-lumber producers does not seem to have attracted sufficient interest in the dispute.

A simple example can illustrate the basic incentive for foreclosure. Suppose two firms, one Canadian and one American, compete in the

${ }^{21}$ It is immaterial to this example whether logs from other countries are tradable.

22 This should be the case regardless of whether the harvester uses a standard constant price contract (a "linear" price), where the payment to a log producer is strictly proportional to the volume that is bought, or a non-linear contract. For instance, a simple form of the latter would be one with a fixed franchise fee, and a linear component. In this latter case, the market would function exactly as if firms were vertically integrated. The linear component would be set equal to the marginal costs of harvesting. If the latter were reduced through a subsidy, the input price of logs for lumber producers would fall. Similarly, if the price of logs were determined through bargaining between the harvester and the lumber producer, a reduction in the marginal costs of producing logs should increase the output of lumber. 
market for lumber. The Canadian firm owns the supply of a type of logs particularly suited for the production of this type of lumber. Would it be in the interest of the Canadian firm to sell such logs to its US competitor? There is a basic reason why it might not want to do this: by providing the US firm with some but not all of this input, the Canadian firm increases the competitiveness of the US firm. The firms will become more alike in terms of costs, and the increased competition will tend to destroy industry profits. The best option may therefore be not to sell to the US firm, thus partly foreclosing it from the lumber market. ${ }^{23}$ The force of this incentive depends on a number of things, including the type of contracts the two firms can sign, and the degree of overlap between the firms' markets.

The outcome in this example is consistent with the view that in the case of vertical integration, a subsidy to Canadian harvesting will harm US lumber producers; this is here "shown" to hold, even taking into account the possibility for the Canadian firm of selling logs to its US counterpart. But the case rests on very special assumptions. Suppose, for instance, that the US lumber producer has access to better marketing channels, so that logs are more valuable when processed by this firm. There will now be an incentive to sell the logs to the US firm. But if the US firm can indeed purchase logs, it will benefit rather than lose from a subsidy to Canadian harvesting. The story will also be more complicated once additional Canadian and US firms are introduced into the picture.

The conclusion is thus that an economically satisfactory injury analysis would be a rather daunting exercise in this case. It would need to take into account the interaction between the contested measures and other government measures, such as export restriction on logs. In particular, a passthrough analysis should be required both in the case of vertical integration and of arm's-length relationships in order to establish a link between the subsidization and the injury to import-competing firms.

\section{Concluding discussion}

The main conclusions from the discussion above are the following:

1. Canadian provincial governments supply timber, and stumpage contracts specify the "prices" at which these goods are traded. These

${ }^{23}$ The possibility that the Canadian lumber producer would leave it to the US firm to monopolize the market is disregarded, since this would probably not be in the Canadian firm's longer-run interest. 
"prices" include not only stumpage fees but also the other obligations stipulated by the contracts.

2. For stumpage programs to subsidize lumber production, they must increase the total volume of logging relative to a no-subsidy benchmark situation. There are two basic ways in which this may occur: more intensive logging per acre and increased harvested acreage. The focus in the dispute is on whether the design of the existing stumpage programs is such as to reduce the price of logs. But the question of whether the stumpage programs are part of a policy to increase or reduce the acreage being harvested seems not to have been addressed.

3. A no-subsidy benchmark cannot be identified in US - Softwood Lumber by simply revoking government measures, since the nosubsidy benchmark must still sensibly involve private harvesting of government land (and such an approach would in any event involve conceptual problems).

4. Economic theory would suggest that the basic undertaking of WTO Members is to avoid behaving in a beggar-thy-neighbor fashion. The no-subsidy benchmark should therefore be defined as the situation in which the design and supply of stumpage contracts are chosen by provincial governments, taking into account legitimate policy objectives, but without any protectionist motives. But this conceptually attractive benchmark would be very hard to identify in practice, even if the contested contracts only specified stumpage fees. For instance, it would require a determination of what are those legitimate policy concerns. The complexity of stumpage programs adds to these conceptual problems and makes the evaluation of the degree of subsidization exceedingly difficult.

5. The private sector no-subsidy benchmark imposed by the SCM Agreement is conceptually problematic; first, since it does not take into consideration whether differences between the private sector benchmark and actual government policy reflect the pursuit of legitimate government policies. Second, the interpretation of the private sector benchmark as referring to prices in existence in the importing country disregards the possibility that the benchmark may be significantly affected by any subsidization. Third, the solution to use foreign market prices as benchmarks is also fraught with problems. There are a number of reasons other than beggar-thy-neighbor behavior why foreign prices may differ from those in the allegedly subsidizing country. 
6. It is not a foregone conclusion that subsidization of Canadian lumber production causes injury to US lumber production, even though this may seem likely to be the case. Other government measures in the context of the timber and lumber industry, such as export restrictions on Canadian logs, may interact in important ways with the terms of stumpage.

7. The Panel's determination that the USDOC did not convincingly demonstrate that stumpage contracts subsidize harvesters, or that all Canadian lumber producers hit by the preliminary measures were subsidized, seems correct from an economic perspective.

Finally, it does not seem implausible that Canadian provincial governments supply more standing timber than they would if they disregarded, for instance, regional employment effects in the domestic lumber industry. It does not seem implausible that they supply less standing timber than would private owners of these forests (regulation permitting) either. This case illustrates some of the conceptual difficulties in defining what a subsidy is.

\section{References}

Bagwell, Kyle and Robert W. Staiger. 2002. The Economics of the World Trading System. Cambridge, MA: MIT Press.

Grossman, Gene M. and Petros C. Mavroidis. 2003. United States - Imposition of Countervailing Duties on Certain Hot-Rolled Lead and Bismuth Carbon Steel Products Originating in the United Kingdom (WTO Doc. WT/DS138/AB/R): Here Today, Gone Tomorrow? In Henrik Horn and Petros C. Mavroidis, Principles of World Trade Law: The World Trade Organization. The Case Law of 2001. Cambridge: The American Law Institute and Cambridge University Press. Janow, Merit and Robert W. Staiger. 2003. United States - The Treatment of Export Restraints as Subsidies Under the Subsidies Agreement of the WTO. In Henrik Horn and Petros C. Mavroidis, Principles of World Trade Law: The World Trade Organization. The Case Law of 2001. Cambridge: The American Law Institute and Cambridge University Press.

Leamer, Edward. 2001. Do Log Export Restrictions in British Columbia Confer A Competitive Advantage on its Softwood Lumber Producers? Submission prepared for the British Columbia Trade Council and the Province of British Columbia.

Nordhaus, William D. 2001. An Economic Analysis of Whether Long-Term Tenure Systems in British Columbian Provincial Forests Provide Countervailable Subsidies to Softwood Lumber Imported into the United States. July 20. 
Submission prepared for the British Columbia Trade Council and the Province of British Columbia.

Sykes, Alan O. 2003. The Economics of WTO Rules on Subsidies and Countervailing Measures. John M. Olin Program in Law \& Economics Working Papers, No. 186: University of Chicago. 